\title{
Differential Androgen Modulation of Acid Phosphatase Isozymes in Primary Cultures of Rat Ventral Prostate Epithelial and Stromal Cells*
}

\author{
JOHN ORLOWSKI $\dagger$ AND ALBERT F. CLARK \\ Departments of Biochemistry and Pathology, Queen's University and Kingston General Hospital, Kingston, \\ Ontario, Canada K7L3N6
}

\begin{abstract}
The influence of androgen on prostate differentiated cell function was investigated using primary cultures of rat ventral prostate epithelial and stromal cells developed from sexually immature animals ( 21 days of age). As a biochemical marker of androgen action, total acid phosphatase activity, which comprises both the secretory and lysosomal isoforms, was measured. Testosterone increased total acid phosphatase activity approximately 2 -fold in epithelial cell cultures. This increase occurred only after the cessation of cell proliferation (i.e. upon reaching a confluent monolayer). In contrast, stromal cells
\end{abstract}

showed no significant change in total acid phosphatase activity in response to androgen. Polyacrylamide gel isoelectric focusing of total acid phosphatase activity from epithelial and stromal cell extracts revealed that secretory acid phosphatase activity was localized exclusively in the epithelial cells while lysosomal acid phosphatase activity was present in both cell types. Furthermore, the androgen-induced increases in epithelial total acid phosphatase activity were found to result from increases in the secretory isoform (Endocrinology 127: 2009-2016, 1990)
$\mathrm{S}_{\mathrm{l}}^{\mathrm{EX}}$ EX steroid hormones play an essential role in regulating the development, growth, and cytodifferentiation of the accessory sex organs in the reproductive tract of a number of species (1-3). There has also been considerable evidence from in vivo and in vitro tissue recombinant experiments demonstrating a central role for epithelial-stromal interactions in the embryonic development of the prostate and other organs (for review, see Ref. 4). In the developing fetal rodent, androgen stimulation of the prostate (urogenital sinus) was shown to be dependent solely on the presence of the androgenreceptor positive urogenital stroma (4-6). Possession or lack of androgen receptors (as in the Tfm mutant genotype) in the urogenital epithelium had no influence on its ability to form prostate glandular structures. Cunha (7) concluded that urogenital epithelial responses to androgen are mediated via trophic factors emanating from the androgen-sensitive urogenital stroma. However, there is some evidence indicating that the urogenital epithelium also may influence the inductive capability of

Received February 14, 1990

Address requests for reprints to: Dr. Albert F. Clark, Department of Biochemistry, Queen's University, Kingston, Ontario, Canada, K7L3N6.

* This research was supported in part by grants from the Medical Research Council of Canada (MT-2338 and MA-10212).

$\dagger$ Current Address: Department of Molecular Genetics, Biochemistry and Microbiology, University of Cincinnati College of Medicine, Cincinnati, Ohio 45267. the urogenital stroma (8), albeit the mechanism is unknown.

These studies have brought into question the cellular role for the epithelial androgen receptor in prostate cell function. Autoradiographic studies $(9,10)$ of androgen binding sites in the rat urogenital sinus and postnatal prostate have demonstrated two phases of androgen action. In the fetal urogenital sinus, nuclear uptake of radioactive androgen was restricted to the stroma surrounding the epithelium. In the postnatal prostate, radioactive androgen uptake by the epithelium increased while that of the mesenchyme decreased, although in the latter it was still present in significant quantities. This suggested a role for the stroma in the development of epithelial androgen receptor activity. Based on these results, these investigators have proposed that fetal prostatic morphogenesis and proliferation are stimulated by androgen-activated stroma, and the functional differentiation of the postnatal prostate epithelium is stimulated directly by androgens. This is an interesting hypothesis that warrants further investigation. At present however, there is little evidence for direct androgen effects on postnatal prostate epithelial and secretory cytodifferentiation independent of stromal influences. Few studies have characterized the effect of androgen on isolated epithelial and stromal cells with regard to their expression of a biochemically defined androgen-dependent protein marker specific to the prostate, such as prostate- 
binding protein $(11,12)$ (also referred to as prostatein) and acid phosphatase (AP) which is known to exist as two distinct molecular species; a secretory and a lysosomal isoform (13). With regard to AP, its usefulness as an androgen-dependent biochemical marker in the whole rat ventral prostate has been demonstrated previously (13-16). Preliminary studies from our laboratory have demonstrated that primary cultures of rat ventral prostate epithelial and stromal cells generated from immature animals can exhibit differentiated cell functions, such as androgen metabolism and AP activity (17).

In order to further characterize the influence of androgen on postnatal prostate development using this cell culture system, we have examined the effects of androgen on AP activity (secretory and lysosomal) in primary cultures of immature rat ventral prostate epithelial and stromal cells. The results demonstrate that androgens can directly modulate prostate epithelial cell function as measured by its influence on AP activity independently of stromal cells.

\section{Materials and Methods}

\section{Animals}

Experiments were performed using immature male SpragueDawley rats (21-22 days old) obtained from Charles River Laboratories Ltd. (Montreal, Quebec, Canada).

All animals were housed in a controlled environment: room temperature $21 \pm 2 \mathrm{C}$; normal atmospheric pressure and humidity and a regulated lighting cycle ( $14 \mathrm{~h}$ light, $10 \mathrm{~h}$ darkness). Tap water and Purina rat chow were available ad libitum.

\section{Reagents}

Sodium chloride, potassium chloride, sodium bicarbonate, sodium dihydrogen phosphate monohydrate, sodium citrate, citric acid, and anhydrous dextrose were of reagent grade and obtained from Canadian Laboratory Supplies (Toronto, Ontario, Canada). Acrylamide/bis (29:1) and riboflavin were obtained from Bio-Rad Laboratories (Mississauga, Ontario, Canada). Ampholines were purchased from Fisher Scientific Co. (Toronto, Ontario, Canada). Hoechst 33258 stain was purchased from Calbiochem-Behring (LaJolla, CA).

Collagenase-type IV (140 U/mg), beef pancreatic DNAse 1, HEPES, Bes, Trizma Base, phenol red, insulin, transferrin, retinoic acid, dexamethasone, $p$-nitrophenyl phosphate, $\alpha$ naphthyl phosphate, fast garnet GBC salt, $\mathrm{L}(+)$ - tartrate, and highly polymerized calf thymus DNA were obtained from Sigma Chemical Co. (St. Louis, MO). Percoll was purchased from Pharmacia Fine Chemicals (Montreal, Quebec, Canada). Fetal bovine serum, chicken serum, F12 medium (powder) without sodium bicarbonate, DME medium (powder) without sodium bicarbonate, and trypan blue exclusion dye were purchased from Flow Laboratories Ltd. (Mississauga, Ontario, Canada). Lyophilized penicillin $(10,000 \mathrm{U} / \mathrm{ml})$, streptomycin $(10,000 \mu \mathrm{g} /$ $\mathrm{ml}$ ), fungizone $(250 \mu \mathrm{g} / \mathrm{ml})$, trypsin (1:250 "Difco" certified), and $0.05 \%$ trypsin- $0.02 \%$ EDTA solution were obtained from Grand Island Biological Company (Grand Island, NY).

Preparation of primary cultures of prostate epithelial and stromal cells

Primary cell cultures were established by enzymatic dissociation of the ventral prostate lobes from immature rats (2122 days) as described previously (18). The resulting mixed cell suspension was subjected to continuous isopycnic Percoll gradient centrifugation to obtain epithelial-and stromal-enriched cell fractions. The epithelial cells were further enriched by the selective attachment procedure (19) which removed the remaining contaminating stromal cells. Based on cell morphology determined by light microscopy, the epithelial and stromal cells represent greater than $95 \%$ of the cells in their respective fractions.

The epithelial- and stromal-enriched cells were resuspended in F12/DME (1:1, vol/vol) culture medium supplemented with $10 \%$ fetal bovine serum, HEPES $(20 \mathrm{~mm}), \mathrm{NaHCO}_{3}(10 \mathrm{~mm})$, insulin $(5 \mu \mathrm{g} / \mathrm{ml})$, transferrin $(5 \mu \mathrm{g} / \mathrm{ml})$, testosterone (T) $(50$ $\mathrm{nM}$ ) (when added), dexamethasone (50 $\mathrm{nM})$, penicillin (100 U/ $\mathrm{ml})$, streptomycin $(100 \mu \mathrm{g} / \mathrm{ml})$, and fungizone $(1 \mu \mathrm{g} / \mathrm{ml}) ; \mathrm{pH}$ 7.6 and maintained in a humidified incubator at $37 \mathrm{C}$ in a gas phase of 98:2 air to carbon dioxide ratio. The culture medium was changed every $48 \mathrm{~h}$.

Cultures of both cell types were monitored daily using a Leitz (Wetzlar) inverted, phase-contrast light microscope. Representative cultures were stained for AP activity or fixed in $100 \%$ methanol for $5 \mathrm{~min}$ and stained with $2 \%$ Geimsa stain for 5$30 \mathrm{~min}$.

\section{Quantification of AP activity}

To determine the androgen-responsiveness of AP activity in epithelial and stromal cell cultures, both cell types were placed in plastic culture flasks ( 75 or $150 \mathrm{~cm}^{2}$ ) and incubated in the absence and presence of $\mathrm{T}(50 \mathrm{nM})$. At selected time intervals, cells were removed from the plastic culture dish surface with a rubber scraper, centrifuged at $1000 \times \mathrm{g}$ for $5 \mathrm{~min}$ at $4 \mathrm{C}$ in a Sorvall refrigerated centrifuge (model RC-3B) and the supernatant discarded. Cell pellets were resuspended in sodium citrate buffer $(0.1 \mathrm{M}, \mathrm{pH} 4.85,4 \mathrm{C})$ and lysed by freezing and thawing $(2$ times at $-20 \mathrm{C}$ ) followed by sonication with a cell sonic dismembrator (Artek Systems Corporation, Farmingdale, NY) at an output control setting of 30 for $25 \mathrm{sec}$ at $4 \mathrm{C}$. Complete cell disruption was confirmed by light microscopy. Aliquots were removed for DNA determination (20). The sonicated material then was sedimented at $13,000 \times g$ for $2 \mathrm{~min}$ in an Eppendorf microcentrifuge (Fisher Scientific, Pittsburgh, PA). The supernatants were collected and either diluted for determinations of protein (21) and total AP activity or frozen at $-20 \mathrm{C}$ in small aliquots before isoelectric focusing (IEF). No significant decrease in activity was observed after 3-4 months in storage. AP activity was assayed as described previously (13) using $p$-nitrophenyl phosphate as substrate. Inhibition of AP 
activity by $\mathrm{L}(+)$-tartrate was calculated as percent of the control AP activity. AP specific activity is expressed as micromoles p-nitrophenyl phosphate hydrolyzed/h-mg DNA.

\section{Polyacrylamide gel IEF of AP activity}

Horizontal analytical IEF of AP enzymes was performed on $7.0 \%$ (wt/vol) polyacrylamide slab gels ( $\mathrm{pH}$ range 4-8) prepared as follows: the composition of the gels included $17.0 \mathrm{ml}$ acrylamide-bis (29:1), ampholines: 1) $1.0 \mathrm{ml}$ ampholine 4-6; 2) 1.5 $\mathrm{ml}$ ampholine 5-8; 3) $0.5 \mathrm{ml}$ ampholine 7-9, $4.0 \mathrm{ml}$ glycerol, and $36.0 \mathrm{ml}$ distilled water. The reagents were mixed after addition of $0.2 \mathrm{ml}$ riboflavin $(2 \mathrm{mg} / \mathrm{ml})$ and poured immediately into the gel plate apparatus. The gels were polymerized by fluorescent light.

The crude cytosol extracts were applied to the top of the gel (anode) with thin strips of filter paper. The strips contained approximately $50 \mu \mathrm{l}$ solution. The gels were electrophoresed for $2 \mathrm{~h}$ at $400 \mathrm{~V}$ followed by $2 \mathrm{~h}$ at $1000 \mathrm{~V}$ using a Brinkman power supply unit (Brinkman Instruments, Inc. Westbury, NY) and the LKB Bromma 2117 Multiphor Electrophoresis unit (Fisher Scientific). The system was cooled to $0 \mathrm{C}$ with a Lauda refrigerating unit model K-2/R (Brinkman Instruments, Inc.). The anode and cathode electrolytes were $1.0 \mathrm{M} \mathrm{H}_{3} \mathrm{PO}_{4}$ and $1.0 \mathrm{M}$ $\mathrm{NaOH}$, respectively. The ampholine $\mathrm{pH}$ gradient was determined by using the LKB 2117-111 Multiphor Surface pH Electrode.

Localization of AP activity in the gels was achieved by incubating the gel with $\alpha$-naphthyl phosphate $(1 \mathrm{mg} / \mathrm{ml})$ and fast garnet $\mathrm{GBC}$ salt $(1 \mathrm{mg} / \mathrm{ml})$ dissolved in $0.1 \mathrm{M}$ sodium citrate buffer $(\mathrm{pH} \mathrm{4.85).} \mathrm{The} \mathrm{IEF} \mathrm{gels} \mathrm{also} \mathrm{were} \mathrm{stained} \mathrm{in} \mathrm{the}$ presence of $\mathrm{L}(+)$-tartrate $(1 \mathrm{mM})$. The gels were stained for 1 to $5 \mathrm{~h}$ at $22 \mathrm{C}$ and then washed with distilled water followed by storage in $1.0 \mathrm{~N}$ acetic acid. Gels were mounted on glass slides, and densitometric scans of the AP bands were performed using a Helena Quik-Quant scanner. Each peak was integrated and calculated as a percentage of the density attributable to all bands for each run. Variations in identical runs were less than $5 \%$ while variations between different scans varied by less than $10 \%$.

\section{Statistics}

Data are presented as the mean \pm SD of a minimum of three determinations. Statistical analysis of data from experiments comparing two separate groups (i.e.; control and test group) was based on a two-sample Student $t$ test $(n<30)$. Statistical analysis of data from more than two groups was performed using a one-way analysis of variance. Comparison of significant differences between means was performed using the NeumanKeuls test at the $1.0 \%$ significance level.

\section{Results}

\section{Effects of $T$ on $A P$ activity}

The effect of exogenous $\mathrm{T}(50 \mathrm{nM})$ on total AP activity in epithelial and stromal cell monolayer cultures as a function of time is presented in Fig. 1. T had a negligible effect on total AP activity in epithelial cells for the first 7 days in culture. This also was the period of rapid cell proliferation regardless of the absence or presence of exogenous androgen (our unpublished observations). Upon reaching confluence, epithelial total AP activity (expressed as micromoles of $p$-nitrophenyl phosphate hydrolyzed per $\mathrm{h} / \mathrm{mg}$ DNA) increased gradually from approximately $14.0 \pm 1.0$ to $20.5 \pm 1.9(P<0.001)$ in the absence of $T$ and to $28.7 \pm 1.4$ in the presence of $T$ at 12 days in culture. In the presence of $\mathrm{T}$, this increase was greater $(40.0 \%)$ than control cultures and was statistically significant $(P<0.001)$. In contrast, stromal cell total AP activity values appeared to be slightly lower in T-supplemented cultures although this difference was not significant except on days 7 and 8 of culture. Overall, in the presence of T (12 days), stromal cell AP activity was approximately $58 \%$ of the level found in epithelial cells.

The effect of $\mathrm{L}(+)$-tartrate $(14 \mathrm{mM})$, a known inhibitor of AP, was assessed in both cell types with time in culture. $\mathrm{L}(+)$-Tartrate, at submaximal concentrations, is known to markedly inhibit lysosomal AP (LAP) while having a lesser effect on secretory AP (SAP) (22). The results are presented in Fig. 2. At 2 days in culture, the levels of percent inhibition of AP activity by $\mathrm{L}(+)$ tartrate were similar, being $52.5 \pm 2.1 \%$ in epithelial cells and $55.0 \pm 1.0 \%$ in stromal cells. In epithelial cells, these levels remained relatively constant for the first 7 days in culture. After cell monolayer confluence, a sharp decrease in the percent inhibition of total AP activity by $\mathrm{L}(+)$-tartrate was observed at 10 days in culture in cells incubated in the absence or presence of exogenous $\mathrm{T}$. These results indicate that epithelial cell total AP activity after 7 days in culture contains an increased relative

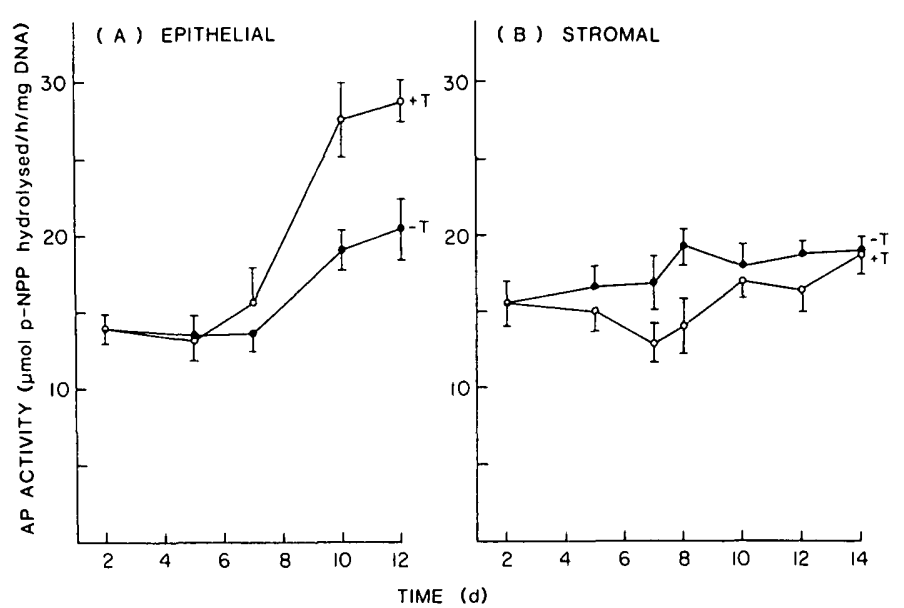

FIG. 1. Effect of $\mathrm{T}$ on AP activity in rat ventral prostate epithelial (A) and stromal (B) cells as a function of time in culture. AP activity was measured in cell extracts isolated from cultures incubated in the absence $(-)$ and presence $(+)$ of $\mathrm{T}(50 \mathrm{nM})$. Results are expressed as the mean $\pm S D(n=3)$. 


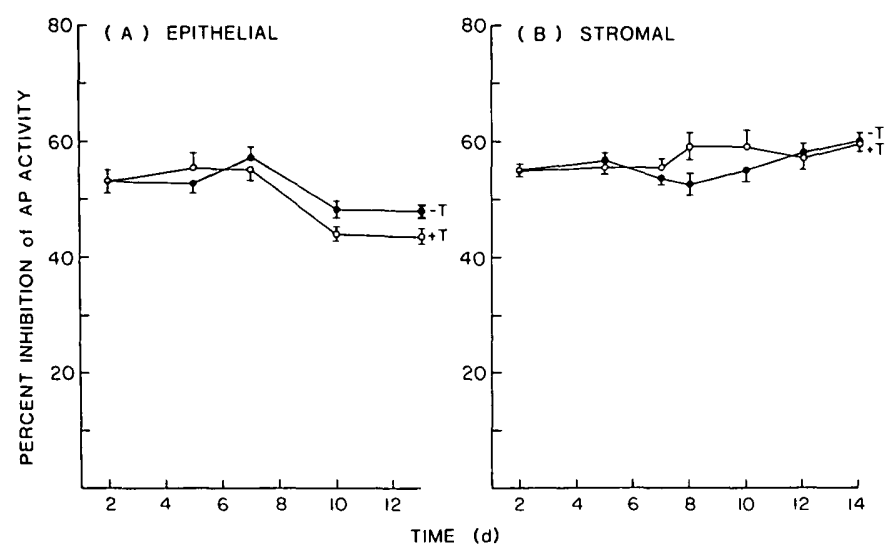

FIG. 2. Percent inhibition of AP activity by $\mathrm{L}(+)$-tartrate in rat ventral prostate epithelial (A) and stromal (B) cells as a function of time in culture. The percent inhibition of AP activity by $\mathrm{L}(+)$-tartrate was measured in cell extracts isolated from cultures incubated in the absence $(-)$ and presence $(+)$ of $\mathrm{T}(50 \mathrm{nM})$. Results are expressed as the mean \pm SD $(n=3)$.

amount of an AP component that is more resistant to inhibition by $L(+)$-tartrate; presumably SAP. The percent inhibition of AP activity, however, was slightly lower $(P<0.05)$ in cells supplemented with exogenous T. In contrast, stromal cells exhibited no significant differences in the percent inhibition of AP activity by $\mathrm{L}(+)$-tartrate in control or treatment cultures throughout the culture period, with the possible exception of day 8.

\section{IEF of $A P$ activity}

To examine in greater detail the changes in total AP activity in cultured cells, IEF of AP activity obtained from cell extracts was performed on polyacrylamide gels. As a preliminary experiment, IEF of AP activities from whole ventral prostate extracts of immature (21-22 days), young adult ( $\sim 65$ days), and young adult rats castrated 14 days previously was performed to allow a comparison with the cultured cells. These results are presented in Fig. 3. Tissue extracts from immature rats show one major band of SAP activity [isoelectric point (pI) $5.20 \pm 0.05]$, an androgen-dependent AP band (ADAP) (pI 6.20 \pm 0.10 ), and one major LAP band (LAPa, pI $7.00 \pm 0.10$ ) as well as one minor LAP band $(\mathrm{LAPb}, \mathrm{pI} 6.75 \pm 0.07$ ). Another minor band (LAPc, pI $6.60 \pm 0.07)$ was observed occasionally after longer periods of staining. AP bands were labeled and identified by their relative $\mathrm{pI}$ values and the use of $\mathrm{AP}$ inhibitor, $\mathrm{L}(+)$-tartrate as previously described (15). By comparison young adult ventral prostate showed increased staining of three bands of SAP below the most anodic SAP band. Because of the close proximity of the SAP bands, it was not possible to consistently distinguish each SAP

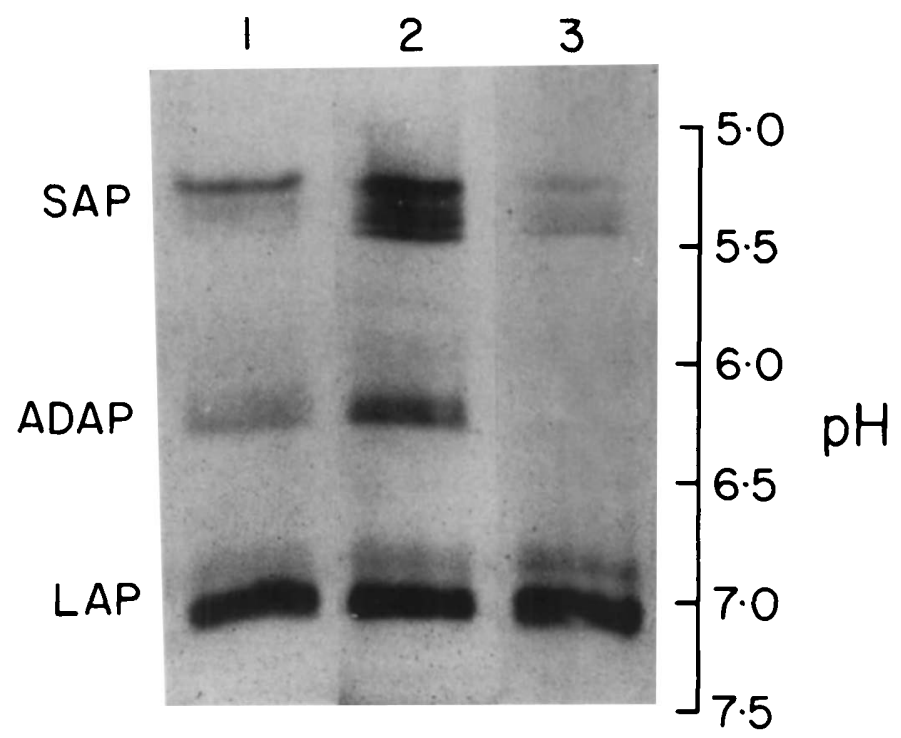

FIG. 3. Distribution of whole rat ventral prostate AP activity on polyacrylamide gels after horizontal IEF. Extracts of prostates $(100 \mu \mathrm{g}$ DNA for each) from immature (lane 1), young adult (lane 2), and young adult rats castrated 14 days previously (lane 3 ) were fractionated on $7 \%$ polyacrylamide gels with a $\mathrm{pH}$ gradient of $4-8$.

band. In contrast, tissue extracts from young adults castrated 14 days previously showed greatly decreased SAP staining, although it did not disappear completely. The ADAP band of activity was completely absent. Also, the staining intensity of the minor $\mathrm{LAPb}$ band increased slightly.

The IEF patterns of AP activity from epithelial cells are presented in Fig. 4A. Lane 1 represents AP activity from cell extracts of freshly isolated epithelial cells from immature rat prostate. The AP banking pattern is similar to that obtained using extracts prepared from whole prostates of immature rats (see Fig. 3, lane 1). After 10 days in culture, epithelial cells grown in the absence (lane 2) or presence (lane 3) of exogenous T (50 nM) showed an increase in the number of SAP bands, although they were difficult to distinguish individually. Furthermore, cultures incubated with $\mathrm{T}$ (lane 3 ) showed an additional increase in staining intensity of the SAP and ADAP bands compared to the untreated cultures. The cultured cells (lane 2 and 3 ) also showed one major (LAPa) and two minor (LAPb and LAPc) bands of LAP activity.

The IEF patterns of AP activity from freshly isolated stromal cells are presented in lane 1 of Fig. 4B. Only three bands of LAP activity were present, there being one major (LAPa) and two minor (LAPb and LAPc) bands. Cultures incubated in the absence (lane 2) or presence (lane 3 ) of exogenous $\mathrm{T}$ for 10 days exhibited similar AP patterns.

The results for epithelial and stromal cells showed that the relative $\mathrm{pI}$ values of the AP enzyme forms appeared 
Fig. 4. Distribution of rat ventral epithelial and stromal cell prostate AP activity on polyacrylamide gels after horizontal IEF. Cell extracts were obtained from epithelial (A) and stromal (B) cells freshly isolated from whole prostate cell (100 $\mu \mathrm{g}$ DNA) suspensions (lane 1) or from equivalent numbers (12 $\mu \mathrm{g}$ DNA) of cultured cells ( 10 days) incubated in the absence (lane 2) or presence (lane 3) of $\mathrm{T}(50 \mathrm{nM})$. Extracts were fractionated on $7 \%$ polyacrylamide gels with a $\mathrm{pH}$ gradient of 4-8.

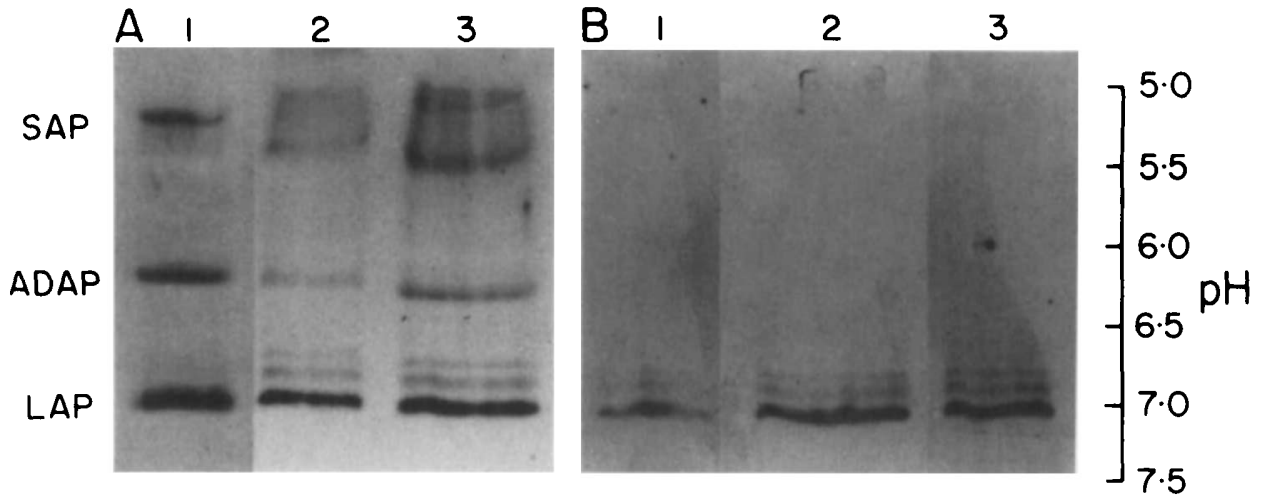

to correspond with those found in whole normal AP activity as secretory or lysosomal; AP activity in these gels also was assayed in the presence of $\mathrm{L}(+)$-tartrate $(1$ $\mathrm{mM})$. This low concentration of $\mathrm{L}(+)$-tartrate has been demonstrated to selectively inhibit LAP activity in extracts from whole prostate $(15,23)$ on IEF gels when $\alpha$ naphthyl phosphate is used as substrate. To quantitatively assess the relative proportions of each AP band, densitometric scans of the gels were performed. The areas under the peaks were calculated and expressed as percentages of the total AP activity under all peaks.

The densitometric scans of the IEF gel results for epithelial cells cultured for 10 days are shown in Fig. 5A, and the calculated percentage distribution of the AP isozymes is presented in Table 1 . Compared to untreated cell cultures [Fig. 5A(1)], addition of exogenous $\mathrm{T}$ [Fig. $5 \mathrm{~A}(2)]$ resulted in significant increases in SAP (39\%) and ADAP (150\%) activity. The combined increase in SAP and ADAP activity was approximately $49 \%(P<$ 0.01 ). This value corresponds with the $45 \%$ increase in total AP activity in T-supplemented compared to unsupplemented cells at 10 days in culture (Fig. 2). When the gels were stained in the presence of $\mathrm{L}(+)$-tartrate [Fig. $5 \mathrm{~A}(3)]$, the LAP bands were decreased preferentially.

The results for stromal cells are shown in Fig. $5 \mathrm{~B}$ and

TABLE 1. Percentage distribution of rat ventral prostate epithelial and stromal cell AP activities in bands observed on IEF gels

\begin{tabular}{|c|c|c|c|c|c|c|}
\hline Cell type & $\mathbf{T}$ & SAP & ADAP & $\mathrm{LAPb}$ & LAPc & LAPa \\
\hline Epithelial & - & $\begin{array}{l}29.9 \pm 3.0 \\
41.6 \pm 5.1\end{array}$ & $\begin{array}{l}2.7 \pm 0.6 \\
6.9 \pm 0.6\end{array}$ & $\begin{array}{l}4.4 \pm 0.9 \\
5.7 \pm 0.8\end{array}$ & $\begin{array}{l}12.6 \pm 0.4 \\
11.5 \pm 0.6\end{array}$ & $\begin{array}{l}50.4 \pm 5.0 \\
34.3 \pm 6.3\end{array}$ \\
\hline \multicolumn{7}{|c|}{ In presence of $\mathrm{L}(+)$-tartrate $(1 \mathrm{mM})$} \\
\hline Stromal & $\begin{array}{l}+ \\
- \\
+\end{array}$ & $\begin{array}{c}55.4 \pm 2.7 \\
\mathrm{ND} \\
\mathrm{ND}\end{array}$ & $\begin{array}{c}17.5 \pm 0.7 \\
\text { ND } \\
\text { ND }\end{array}$ & $\begin{array}{c}\text { ND } \\
12.0 \pm 2.4 \\
5.6 \pm 2.0\end{array}$ & $\begin{array}{c}\text { ND } \\
23.2 \pm 1.4 \\
16.7 \pm 1.9\end{array}$ & $\begin{array}{l}28.1 \pm 1.6 \\
64.9 \pm 2.0 \\
77.9 \pm 2.5\end{array}$ \\
\hline \multicolumn{7}{|c|}{ In presence of $L(+)$-tartrate $(1 \mathrm{mM})$} \\
\hline & + & ND & ND & ND & ND & 100.0 \\
\hline
\end{tabular}

Epithelial and stromal cell cultures were incubated for 10 days in the absence ( -$)$ and presence $(+)$ of $\mathrm{T}(50 \mathrm{nM})$. The gels were stained for AP activity in absence and presence of $\mathrm{L}(+)$-tartrate $\cdot$ Results represent the mean $\pm S D(n=3)$. ND, Not detected.
Table 1. In the presence of $\mathrm{T}$ [Fig. 5B(2)], small increases $(19.9 \%, P<0.01)$ in the major LAPa band relative to the other minor LAPb and LAPc bands were observed. $\mathrm{L}(+)$-Tartrate greatly decreased staining [Fig. 5B(3)] for all the LAP bands, leaving only small amounts of LAPa to account for the remaining AP staining.

\section{Discussion}

In the present study, ventral prostate epithelial cells isolated from immature rats entered a rapid phase of cell proliferation after being placed in culture in the absence or presence of exogenous androgen. Those grown in the presence of androgen proliferated at a slightly faster rate as evidenced by a more rapid increase in DNA concentration per culture dish area and by reaching confluency approximately 1-2 days earlier (Orlowski, J., and A. Clark, unpublished observations). Thus significant androgen levels do not appear to be necessary although they have some influence on the rate of cell proliferation. The androgen levels as measured by RIA (24) in the serum-supplemented media were low [0.06 $\mathrm{nM} \mathrm{T}$ and 0.03 nM $5 \alpha$-dihydrotestosterone ( $5 \alpha$-DHT)]. Because of active androgen metabolism by the epithelial cells in culture (17) and the fact that the media are changed only every $48 \mathrm{~h}$, the average androgen levels will be very low. Upon reaching a confluent monolayer ( 7 days), there was a cessation of DNA synthesis, and the cells appeared to engage in a maturation process that culminated in increased expression of AP activity. These observations are similar to those found for adult canine prostate epithelial cell cultures that were maintained in dialyzed serum-supplemented culture medium (25-27).

These results now have been extended to show that addition of supraphysiological concentrations of androgen augment total AP activity in epithelial cell cultures above that observed in unsupplemented cultures, but only after cell proliferation has ceased. In the androgendeficient cultures, AP activity also increased after cessation of cell proliferation but to a much smaller extent. 
(A) EPITHELIAL

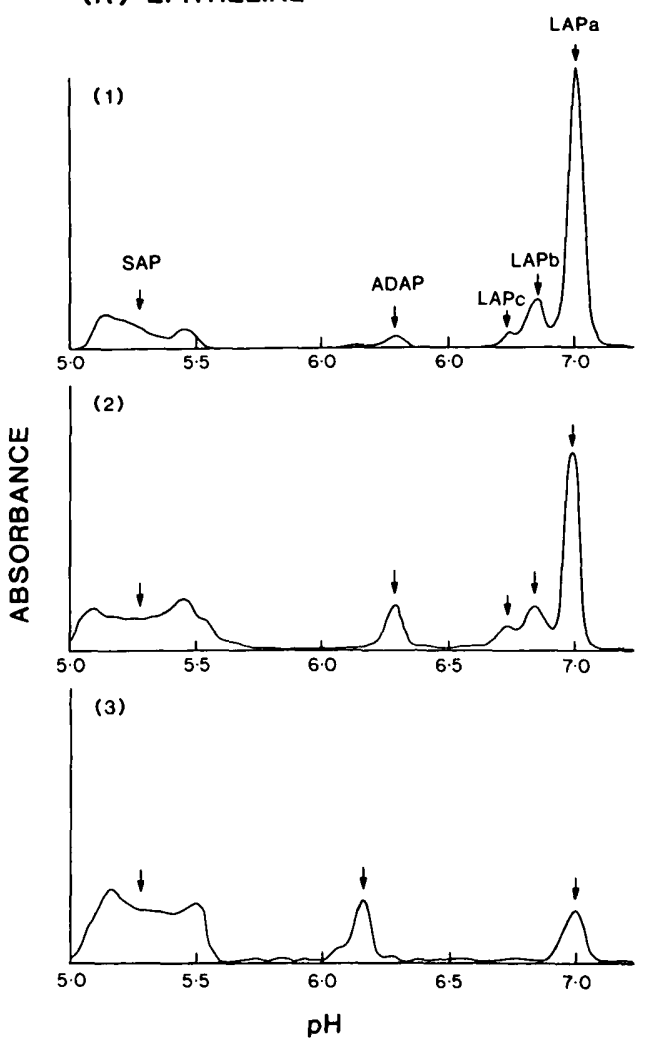

(B) STROMAL
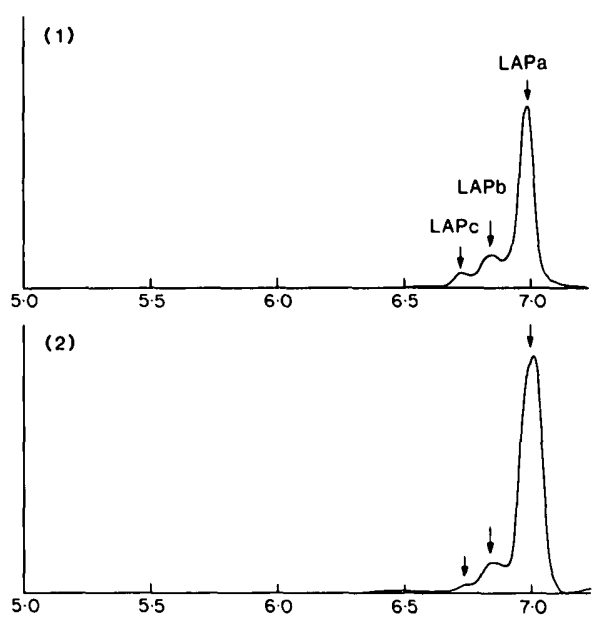

(3)

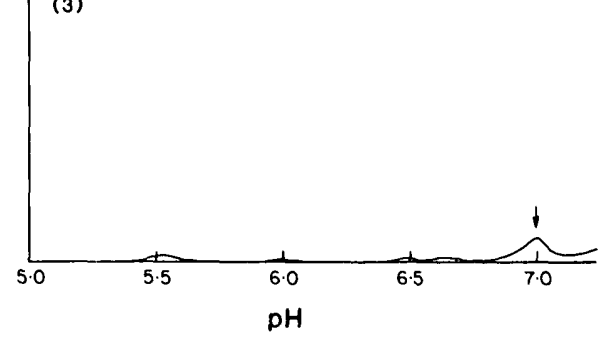

FIG. 5. Densitometric scans of rat ventral prostate epithelial (A) and stromal (B) cell AP activity on polyacrylamide gels after horizontal IEF. The scans represent AP activity obtained from cells cultured in the absence (1) and presence (2) of $\mathrm{T}$ ( $50 \mathrm{nM}$ ) for 10 days. Cells from the latter samples were also stained in the presence $(3)$ of $L(+)$-tartrate (1 mM). induction of proteins such as SAP is postponed until after cell replication. This indicates a differential control of androgen-dependent genes to induction by androgen (i.e.;5 $\alpha$-DHT), and this mechanism may be related to the concentration of androgen receptors or acceptors present in the nucleus. It can be inferred from these observations that the affinities of the nuclear acceptor sites associated with the different genes for the androgen receptor are probably not equal.

In the present study, IEF analysis of AP activity from immature and adult rat ventral prostate or cultured immature epithelial cells revealed that androgens stimulated an increase in the number of SAP activity bands. This accounted for the overall increase in total AP activity. Increased SAP activity in epithelial cells was correlated with a decreased percent inhibition of total AP activity by $\mathrm{L}(+)$-tartrate. This was due to the fact that SAP is more resistant to inhibition by $\mathrm{L}(+)$-tartrate relative to $\operatorname{LAP}(15,23)$.

While it was difficult to define the number of bands in the cultured epithelial cells, the pI range of the SAP bands corresponds to that found in whole tissue. Based on a previous study (15), it has been suggested that ADAP is a precursor for the most anodal SAP band and that the latter is then a precursor for the other SAP activities. Studies on human prostate AP activity (33) have yielded results that have some similarities to the studies using rat tissue. The results suggest that this 
biosynthetic interrelationship may also involve controlling the state of glycosylation of AP. Androgen control of protein glycosylation has been shown previously for rat epididymis (34). The results could be partially explained by interconversions of existing AP forms. However, the increase in total AP activity suggests an androgen stimulation of AP synthesis. Our laboratory also has evidence from in vivo studies involving the use of the inhibitor of protein synthesis, cycloheximide (Downey, J., and A. F. Clark, unpublished results), which supports the existence of androgenic regulation at both the level of enzyme synthesis and protein glycosylation. SAP, therefore, is a sensitive marker of prostatic secretory function. Also, the androgen-induced increases in SAP activity relative to LAP activity suggest that androgens are acting specifically on SAP synthesis and not stimulating general cell protein synthesis. LAP activity, therefore, can serve as an internal control standard for androgen-induced gene expression.

In contrast, stromal cell total AP activity did not respond significantly to T or $5 \alpha$-DHT. IEF studies of stromal cell extracts revealed only the presence of three bands of LAP; one major (LAPa) and two minor (LAPb and LAPc) bands. These bands of AP activity were confirmed as being lysosomal as determined by their $\mathrm{pI}$ values and high sensitivity to inhibition by $\mathrm{L}(+)$-tartrate.

The results indicate that androgens can directly influence the secretory function of postnatal prostate epithelial cells independent of the stroma. Therefore, at this stage of prostate development, trophic factors secreted by stromal cells may not be involved directly or at least are no longer required for specific androgen-regulated gene expression in epithelial cells. This is consistent with the previous suggestion based on morphological studies $(9,10)$ that prostate development involves two phases of androgen action; the first phase involves prostate morphogenesis mediated by the androgen-activation of the mesenchyme, and the second phase involves the functional differentiation (i.e. SAP activity) of the postnatal prostate epithelium by direct androgen stimulation.

In summary, it appears that there is a differential androgen regulation of the various AP enzyme isoforms at the level of enzyme synthesis and possibly at the level of glycosylation. This cell culture system should provide a unique opportunity for investigation of the mechanisms involved in androgen-dependent processing of similar secretory and lysosomal gene products. At present, studies on the androgen sensitivity of stromal cells are hampered by the lack of an adequate biochemical marker. In this regard, alkaline phosphatase activity in prostate stromal tissue has been reported to be stimulated by androgens (35). This may serve as a useful parameter of androgen action in stromal cell cultures, although this remains to be determined. In conclusion, changes in AP characteristics can serve as a useful parameter of androgen-mediated actions in rat ventral prostate epithelial cell cultures.

\section{References}

1. Jost A 1965 Gonadal hormones in the sex differentiation of the mammalian fetus. In: DeHaan RL, Ursprung H (eds) Organogenesis. Holt, Rienhart and Winston, New York, p 611

2. Price D, Ortiz E 1965 The role of fetal androgens in sex differentiation in mammals. In: DeHaan RL, Ursprung $\mathrm{H}$ (eds) Organogenesis. Holt, Rienhart and Winston, New York, p 629

3. Wilson JE, George FW, Griffin JE 1981 Hormonal control of sexual development. Science 211:1278

4. Cunha GR, Donjacour AA, Cooke PS, Mee S, Bigsby RM, Higgins SJ, Sugimura Y 1987 The endocrinology and developmental biology of the prostate. Endocr Rev 8:338

5. Cunha GR, Lung B 1978 The possible influence of temporal factors in androgenic responsiveness of urogenital tissue recombinants from wild-type and androgen insensitive (Tfm) mice. J Exp Zool 205:181

6. Lasnitzki I, Mizuno T 1980 Prostatic induction: interaction of epithelium and mesenchyme from normal wild-type mice and androgen-insensitive mice with testicular feminization. J Endocrinol 85:423

7. Cunha GR 1984 Androgenic effects upon the prostatic epithelium are mediated via trophic influences from stroma. In: Kimbal FA, Buhl AE, Carter DB (eds) Progress in Clinical and Biological Research. Alan R. Liss, Inc., New York, vol 145:81

8. Chung LWK, Matsuwra J, Runner MN 1984 Tissue interactions and prostatic growth. Induction of adult mouse prostatic hyperplasia by fetal urogenital sinus implants. Biol Reprod 31:155

9. Shannon JM, Cunha GR 1983 Autoradiographic localization of androgen binding in the developing mouse prostate. The Prostate 4:367

10. Takeda H, Mizuno T, Lasnitzki I 1985 Autoradiographic studies of androgen-binding sites in the rat urogenital sinus and postnatal prostate. J Endocrinol 104:87

11. Parker MG, Scrace GT, Mainwaring WIP 1978 Testosterone regulates the synthesis of major proteins in rat ventral prostate. Biochem J 170:115

12. Heyns W, Peeters B, Morris J, Rombauts W, DeMoor P 1979 Androgen-dependent synthesis of a prostatic binding protein by rat prostate. J Steroid Biochem 11:209

13. Tenniswood M, Bird CE, Clark AF 1976 Acid phosphatase: androgen dependent marker of rat prostate. Can J Biochem 54:350

14. Tenniswood M, Abrahams PP, Bird CE, Clark AF 1978 Effects of castration and androgen replacement on acid phosphatase activity in the adult rat prostate gland. $J$ Endocrinol 77:301

15. Downey J, Mahan D, Flynn TG, Bird CE, Clark AF 1983 Rat prostatic acid phosphatase: androgenic control of isoelectric focussing patterns. Can J Biochem Cell Biol 61:744

16. Orlowski J, Bird CE, Clark AF 1988 Androgen metabolism and regulation of rat ventral prostate growth and acid phosphatase during sexual maturation. J Endocrinol 116:81

17. Orlowski J, Clark AF 1986 Androgen metabolism and actions in rat ventral prostate epithelial and stromal cell cultures. Biochem Cell Biol 64:583

18. Orlowski J, Bird CE, Clark AF 1982 Preparation of epithelial and stromal cell fractions from immature rat prostatic tissue using Percoll gradients. J Androl 3:232

19. Ofner P, Vena RL, Terracio L, Douglas WHJ 1982 Comparative $\mathrm{C}_{19}$-radiosteroid metabolism in primary monolayer cultures of epithelial cells and fibroblasts from rat ventral prostate, canine prostate and rat lung. J Androl 3:269

20. Labarca C, Paigen K 1980 A simple, rapid and sensitive DNA assay procedure. Anal Biochem 102:344

21. Miller GL 1959 Protein determination for large numbers of samples. Anal Chem 31:964 
22. Vanha-Perttula T, Nieme R, Helminen HJ 1972 Separate lysosomal and secretory acid phosphatases in the rat ventral prostate. Invest Urol 9:345

23. Jauhiainen A, Karkkainen-Rytoluceto R, Vanha-Perttula T 1983 Separation of acid phosphatases in the rat ventral prostate by gel filtration, isoelectric focusing and chromatofocussing. The Prostate $4: 91$

24. Abraham GC, Manlimos ES, Solis M, Wickman AC 1975 Combined radioimmunoassay of four steroids in one ml of plasma. II. Androgens. Clin Biochem 8:374

25. Chevalier S, Bleau G, Roberts KD, Chapdelaine A 1980 Characterization of canine prostatic cells from normal and hyperplastic glands. Mol Cell Endocrinol 20:59

26. Chevalier S, Bleau G, Roberts KD, Chapdelaine A 1981 Proliferation and differentiation of canine prostatic epithelial cells in culture. Mol Cell Endocrinol 24:195

27. Dionne FT, Chevalier S, Bleau G, Roberts KD, Chapdelaine A 1983 Induction of acid phosphatase synthesis in canine prostatic epithelial cells in vitro. Mol Cell Endocrinol 33:113

28. Page MJ, Parker MG 1983 Androgen-regulated expression of a cloned rat prostatic $\mathrm{C} 3$ gene transfected into mouse mammary tumour cells. Cell 32:495

29. Chevalier S, Bleau G, Roberts KD, Chapdelaine A 1984 Nonsteroidal serum factors involved in the regulation of the proliferation of canine prostatic epithelial cells in culture. The Prostate 5:503

30. Rennie PS, Bruchovsky N, Hook SL 1978 Androgen regulation of a tissue specific isoenzyme of acid phosphatase in rat ventral prostate. J Steroid Biochem 9:585

31. De Larminat M-A, Rennie PS, Bruchovsky N 1981 Radioimmunoassay measurements of nuclear dihydrotestosterone in rat prostate. Biochem J 200:465

32. Tenniswood MP, Abrahams PP, Bird CE, Clark AF 1981 Small doses of $5 \alpha$-dihydrotestosterone mimic the effects of $5 \alpha$-androstane-3 $\beta, 17 \beta$-diol on acid phosphatase activity in the adult rat prostate. Mol Cell Endocrinol 22:223

33. Lam WK, Yam L, Wilbur H, Taft, Li C-Y 1979 Comparison of acid phosphatase isoenzymes of human seminal fluid, prostate and leukocytes. Clin Chem 25:1285

34. Lusem ND, DeLarminat MA, Tezon JG, Blaquier JA, Belocopitow E 1984 Androgen dependence of protein $\mathrm{N}$-glycosylation in rat epididymus. Endocrinology 114:1448

35. Shiojiri N, Mizuno T 1981 Mesenchymal alkaline phosphatase in rat prostatic bud formation. Dev Growth Diff $23: 460$ 